\title{
MESOZOIC OCEANIC TERRANES OF SOUTHERN CENTRAL AMERICA-GEOLOGY, GEOCHESMISTRY AND GEODYNAMICS
}

\author{
Kennet E. Flores (2009)
}

The Northwestern edge of the modem Caribbean Plate, located in central Middle America (S-Guatemala to N-Costa Rica), is characterized by a puzzle of oceanic and continental terranes that belonged originally to the Pacific façade of North America. South of the Motagua Fault Zone, the actual northern strike slip boundary of the Caribbean Plate, three continental slivers (Copán, Chortis s. str. and Patuca) are sandwiched between two complex suture zones that contain HP/LT mafic and ultramafic oceanic rocks: The Motagua Mélanges to the North, extensively studied in the last ten years and the newly defined Mesquito Composite Oceanic Terrane (MCOT) to the South. No modern geological data were available for the oceanic terrane located in the southern part of the so called continental "Chortis Block". Classically, the southern limit of this block with the Caribbean Large Igneous Province (CLIP) was placed at a hypothetical fault line connecting the main E-W fault in the Santa Elena Peninsula (N-Costa Rica) with the Hess Escarpment. However, our study in eastern Nicaragua and northwestern Costa Rica evidences an extensive assemblage of oceanic upper mantle and crustal rocks outcropping between the Chortis/Patuca continental blocks and the CLIP. They comprise collided and accreted exotic terranes of Pacific origin recording a polyphased tectonic history.
We distinguish: 1- The MCOT that comprises a Late Triassic to Early Cretaceous puzzle of oceanic crust and are-derived rocks set in a serpentinite matrix, and 2- The Manzanillo and Nicoya Terranes that are made of Cretaceous plateau-like rocks associated with oceanic sediments older than the CLIP. This study has been focused on the rocks of the MCOT. The MCOT comprises the southern half of the former "Chortis Block" and is defined by 4 corner localities characterized by ultramafic and mafic oceanic rocks of Late Triassic, Jurassic and Early Cretaceous age: 1 - The Siuna Serpentinite Mélange (NE-Nicaragua), 2- The El Castillo Mélange (Nicaragua-Costa Rica border), 3- DSDP Legs 67 and 84 (Guatemala fore-are basin), and 4- The Santa Elena Peridiotite (NWCosta Rica).

The Siuna Serpentinite Mélange (SSM) is a HP/LT subduction zone mélange set in a serpentinite matrix that contains Oceanie crust and arcrelated greenschist to blueschist/eclogite facies metamafic and metasedimentary blocks. Middle Jurassic (Rajocian-Bathonian) radiolarites are found in original sedimentary contact with arc-derived greenstones. Late Jurassic black detrital chert possibly formed in a marginal (fore-arc?) basin shortly before subduction. A phregnite ${ }^{40} \mathrm{Ar} /{ }^{39} \mathrm{Ar}$ -cooling age dates the exhumation of the high pressure rocks as 139 Ma. The El Castillo Melange 
(F.CM) is composed of serpentinite matrix with OIB metabasalts and Late Triassic (Rhaetian) red and green radiolarite blocks. Recent studies of the DSDP Legs 67/84 show that the Guatemala/ Nicaragua fore-arc basin is composed of a pile of ultramafic, mafic (OIB-like) and arc related rocks with ages ranging from Late Triassic to Campanian. Finally, the Santa Elena peridiotites that mark the limit of the MCOT with the Manzanillo/Nicoya Terranes and correspond to an association of ultramafic rocks that comprise peridiotites, dunites and chromites of abyssal and fore-arc origin.

The SSM is the result of a collision between a Middle Jurassic island arc and the Patuca Terrane, a fragment of the Western N-American active continental margin. The Siuna Mélange
(SSM) and the South Montagua Mélange share common characteristics with the Pacific $\mathrm{N}$ - American suture zone (E-Franciscan and Vizcaino mélanges), in particular, the Mesozoic ages of HP/LT metamorphic and the arc-derived blocks. For us, these mélanges imply an originally continuous, but slightly diachronous suture that affected the entire W-American active margin. It may imply the arrival and collision of an exotic intraoceanic arc (Guerrero-Phoenix) related to the origin of the Pacific Plate that initiated as a back arc basin of this arc. The present disposition of the fragments of this suture zone is the result of a northward shift of the active left-lateral strike slip motion between the N-American and the Caribbean Plates. 